\title{
Building Theory on the Negotiation Capability of the Firm: Evidence from Ryanair
}

\author{
Post-review, accepted for publication in the Journal of Knowledge Management \\ Dr Andrea Caputo \\ University of Lincoln, Lincoln, UK \\ acaputo@lincoln.ac.uk \\ Dr Adrian Borbély \\ Négocier - Résoudre - Initier - Accompagner (NRIA), Nice, France \\ adrian@nria.fr \\ Prof. Marina Dabic \\ University of Zagreb, Zagreb, Croatia \\ mdabic@efzg.hr \\ Nottingham Trent University, Nottingham, the UK \\ marina.dabic@ntu.ac.uk
}

\begin{abstract}
Purpose: In an attempt to build upon existing theory, this paper investigates the potentially reciprocal relationship between negotiation and strategy, and strives to contribute towards a better understanding of the ways in which organizations negotiate.

Design/methodology/approach: Built upon the integration of two different bodies of literature, negotiation and strategy, and on the analysis of the case of Ryanair, this paper argues for an integrated approach to negotiation and organizational capabilities.

Findings: The case study allows for a clearer understanding of how negotiation capability can play a significant role in supporting the creation and sustainment of competitive advantage, even under unfavorable industry settings.

Originality/value: The paper contributes to theoretical development by offering new and insightful explanations of firms' behavior, moving beyond the classic interpretation of industry dynamics, such as bargaining power. This study has implications for both practice and research, as it offers a better and more holistic understanding of the strategy making process and the foundations of its success.
\end{abstract}

Keywords: Negotiation, Knowledge Management, Capabilities, Ryanair, Strategy, Theory Building 


\section{Building Theory on the Negotiation Capability of the Firm: Evidence from Ryanair}

\section{Introduction}

\subsection{Research Background and Gaps}

The network of negotiations taking place across an organization contributes strongly to the success of the overall strategy of the firm; in other words: "organizations that look past negotiation as a core capability do so at their own peril" (Movius and Susskind, 2009, p. 5). This blunt statement from two leading negotiation scholars calls for an organization-wide, strategic perspective on negotiation practices. With this paper, we intend to respond to this call by adopting a theory building approach (Eisenhardt and Graebner, 2007) in order to investigate the ways in which negotiation, seen as an organizational capability rather than an individual capability, relates to and contributes to competitive advantage. As our literature review will demonstrate, such issues have been widely overlooked in research, with strategy merely acknowledging the negotiation activities within an organization and identifying the concept of bargaining power in a market (Moatti et al., 2014); negotiation focusing only on an individual level (Ogliastri and Quintanilla, 2016); and only the stakeholder theory stream of literature calling for a systemic perspective which, unfortunately, does not examine negotiations in any depth (Ackermann and Eden, 2011). Consequently, a systematic understanding of the ways that negotiation can contribute to competitive advantage, beyond the mere acknowledgement of the fact that it does, is still missing in both negotiation and strategy literature. This issue is partly a result of the silence within scholarly literature on how negotiation knowledge is created, stored, and shared within organizations (e.g., Nadler et al., 2003). By integrating these two bodies of literature (negotiation and strategy) and unveiling a case study, we aim to give academic recognition to negotiation as an organizational capability, opening up a new field of research in an attempt to provide new insight into how firms can better their chances of survival in today's turbulent times.

Following Movius and Susskind (2009), we adopt a broad definition of negotiation which is inclusive of all joint decision-making processes, in which managers and leaders must reach agreements with the organization's stakeholders. Unlike other scholars, we do not consider negotiations to be unique occurrences; for instance, negotiation with a supplier for specific maintenance services, or a single event in the history of an organization, even if of strategic importance (Ring and van de Ven, 1994). Rather, we approach it as the entirety of the 
organization's negotiated relationships, both internal - individual and collective employment negotiations, interpersonal and interdepartmental relations, etc. - and external - sales, purchasing, lobbying, etc. For the purpose of this study, we also deliberately choose not to adhere to a specific theoretical view of strategy in light of the nascence of our topic of research, as will be demonstrated in the paper.

\subsection{Research Aims and Value}

The aim of this paper is to lay the foundations for the development of a comprehensive and scientific understanding of the intricate relationship between a firm's strategy and its capability to succeed in negotiating productive internal and external relationships. Our research contributes to the theoretical development of negotiation as an organizational capability and strives to demonstrate that, through negotiation, some firms (such as Ryanair) may achieve a superior and counterintuitive competitive advantage, despite unfavorable external conditions and, in theory, a disadvantage of bargaining power. Our study proposes a model that shows a potentially reciprocal relationship between strategy and negotiation, as negotiation practices are influenced by an organization's strategy and thus play a large role in strategy making, leading to competitive advantage.

Given the limited theoretical resources available and the novelty of our approach, we contribute to these bodies of literature by inductively investigating a case study analysis that will serve to build theory (Eisenhardt and Graebner, 2007; Yin, 2014). Consistently with previous research (e.g., Stary, 2014), we rely on a single case, namely the airline firm Ryanair, as it exemplifies the ways in which an idiosyncratic and structured corporate approach to the management of knowledge around negotiations can be central to a firm's strategy and form the basis of its competitive advantage.

The paper is structured as follows: we initially review the scarce amount of literature in this area in order to demonstrate that this topic, which appears to be of pivotal importance from the perspective of managers and practitioners, has been under-researched so far; secondly, we present the research design and the case; and, finally, we construct theory, filling the gap between negotiation and strategy and subsequently providing suggestions on how to maximize the contribution of negotiation to aid in the success of a strategy. 


\section{Literature review: the gap at the interplay of strategy and negotiation}

We reviewed the two relevant streams of literature - one in strategy and one in negotiation - to try to outline the contributions and limitations of the current academic knowledge on negotiation as an organizational capability and its interplay with strategy. In doing so, we stumbled upon a bulk of references relating to questions that did not entirely correlate with our investigations but were interesting nontheless; for example, the industrial economics perspective on bargaining power (Kim, 1988; Michael, 2000; Moatti et al., 2014). Other contributions focused on specific types of negotiations that can have strategic importance for an organization, such as exchanges between headquarters and subsidiaries (Dörrenbächer and Gammelgaard, 2006) or negotiations with governments (Weiss, 1990). The majority of the investigated literature concerned collaborative forms of strategy, such as mergers and acquisitions (Jemison and Sitkin, 1986; Walsh and Fahey, 1986; Dierickx and Koza, 1991), joint ventures (Brouthers and Bamossy, 1997; Lee, Chen, and Kao, 1998; Luo, 1999; Yan and Gray, 2001; Luo and Shenkar, 2002), or strategic alliances and outsourcing (Lippman and Rumelt, 2003). Taken together, these papers acknowledge the fact that specific strategic moves take place through high-level negotiations (Ring and van de Ven, 1994). For example, research on acquisitions remains controversial in terms of the reasons why well-designed acquisition processes fail (Kummer and Steger, 2008); on this subject, strategic fit cannot be considered to be the only variable (Porter, 1996). The process of negotiating the acquisition and integrating the target into the parent firm, another setting for multiple negotiations, should also be considered as one of the drivers of success (Jemison and Sitkin, 1986; Dierickx and Koza, 1991). Similarly, research on joint ventures shows different patterns in organizations' behaviors, particularly with regards to contract negotiations (Lee et al., 1998; ; Luo, 1999; Luo and Shenkar, 2002).

A broader perspective on negotiation is taken by only a few strategy scholars. Pahl and Roth (1993) identify some key variables in strategy formation that may impact conflictproneness and negotiation practices between headquarters and foreign subsidiaries; similarly, it has been posited that the level of centralization of some strategic decisions produces a structured and idiosyncratic way of negotiating throughout the organization (Quélin and Duhamel, 2003).

A different stream of research looks at the interplay between conflict and strategy. Firstly, conflict within strategy-making teams may hinder strategy formulation (Elbanna et al., 2011; Parayitam and Dooley, 2011). Secondly, well-designed strategic moves may backfire at 
the implementation stage simply because of failed human interactions further down the line (Mintzberg et al., 1998). Jemison and Sitkin (1986), while studying the acquisition process as a determinant of acquisition activities and outcomes, advocate the importance of negotiating practices in the acquisition process with reference to the success of the operation - particularly the acceptance of the operation by the personnel (Beatty and Schneier, 1997). Indeed, lack of transitional support may result in dissatisfaction and low productivity (Jemison and Sitkin, 1986).

Further literature examines the ways in which negotiation behavior may specifically impact strategy implementation. In this respect, one should immediately think of stakeholder theory (Freeman, 2010). On the one hand, this theory states the problem, that is: to be successful, an organization has to negotiate productive relationships with key stakeholders (Brouthers and Bamossy, 1997; Freeman, 2010; Mintzberg and Lampel, 2012). On the other hand, it neglects to focus on how one should pursue such an objective on an everyday basis, leaving such questions mostly to the field of negotiation (Lax and Sebenius, 1986). Here, beyond stakeholder management, the question becomes whether there are negotiation practices, tailored to a given strategic positioning, which favor, or conversely hinder, the successful implementation of one's strategy.

The reviewed literature rarely considers negotiation from a systematic, organizationwide perspective that covers all of its forms - from sales and purchasing to everyday management negotiations - and addresses their relation to strategy. This may be a consequence of the fact that the different approaches taken by the two bodies of literature (strategy and negotiation) have thus far somehow prevented cross-fertilization. Negotiation research has focused mostly on the behavioral aspects of human interactions (Lewicki et al., 2014) and ignored the contextual aspects of such interactions, which only seem to be addressed in political science literature (Zartman, 1977, 1988) and, more recently, in employment relationship literature (Munduate et al., 2012). Conversely, strategic literature looks at stakeholder management without clearly entering into the specificities of how these relationships are established, maintained, and improved when needed (Ackermann and Eden, 2011; Mazzola and Kellermanns, 2010). Taken together, these bodies of literature leave a gap in our understanding of how organizations function when negotiating and, more specifically, how strategy and negotiation processes are intertwined.

Even if the literature on strategy, taken in its entirety, seems to infer the existence of the relationship between negotiation and strategy, it does not provide a holistic, general framework to help us to understand how such an intricate relationship actually develops. 
However, as demonstrated by our case study, opportunities arise from the possible integration of negotiation concepts into the study of strategy.

\section{Research design}

\subsection{Justification for the theory building approach}

This study adopts a theory building approach which "is a research strategy that involves using one or more cases to create theoretical constructs, propositions and/or midrange theory from case-based, empirical evidence" (Eisenhardt and Graebner, 2007, p. 25). The case study method (Yin, 2014) has increasingly received attention from management scholars over recent decades and has been widely used in the fields of management and strategy (Lin et al., 2015; Manzini et al., 2016; Salvato, 2009). Theory building through a case study is especially appropriate in new topic areas as a result of its likelihood of generating novel theory in an empirically valid manner (Eisenhardt, 1989). The justification for our use of the case study method in our research can be found directly in Eisenhardt's words: "there are times when little is known about a phenomenon, current perspectives seem inadequate because they have little empirical substantiation, or they conflict with each other or common sense. Or, sometimes, serendipitous findings in a theory-testing study suggest the need for a new perspective. In these situations, theory building from case study research is particularly appropriate because theory building from case studies does not rely on previous literature or prior empirical evidence" (Eisenhardt, 1989, p. 532). The methodology allows for the investigation of a topic as a distinct "experiment", without isolating the phenomena from the context as it emphasizes "the rich, real-world context in which the phenomena occur" (Eisenhardt and Graebner, 2007, p. 25). Adopting a theory building methodology based on a case study allowed for cross-comparisons and the triangulation of data gathered from multiple secondary sources, such as reports, magazines, and newspapers.

Our emphasis in this study is on inductively developing a new theoretical approach. The concept of negotiation as an organizational capability may sound quite obvious from a managerial and practical perspective, however management research is yet to develop theory around the construct. It is almost trivial to say that a firm that negotiates better than their competitors has a competitive advantage. Yet, again, existing theory does not provide a sound review of the ways in which negotiation can be investigated at the organizational level, i.e. what it means for a firm to negotiate more effectively, how a firm can systematically improve 
its negotiations (beyond training its key actors), and how to fully grasp the relationship between negotiation and strategy.

\subsection{Case study selection}

We base our paper on a single case, a method seemingly consistent with the novelty of the researched topic and its accessibility, as we aim to richly describe the existence of a phenomenon (Siggelkow, 2007; Urbinati et al., 2018). Our case was selected through theoretical sampling (Eisenhardt and Graebner, 2007) and Ryanair was chosen because of its suitability in illuminating the relationship between the firm's idiosyncratic organizational capability to negotiate and their leadership position on the ultra-competitive European airline market (Kangis and O'Reilly, 2003).

More specifically, Ryanair was selected firstly because the airline sector offers a wide and deep range of publicly available sources, due to its regulatory components; and it has been extensively studied in the field of strategy, proving its relevance to the topic (e.g., Shakun, 1991; Smith, Grimm, Gannon, and Chen, 1991; Porter, 1996; Grant, 2010). Ryanair has been utilized in the past in investigations concerning various strategic issues, such as strategy in dynamic markets (Kangis and O'Reilly, 2003), business models (Casadesus-Masanell and Ricart, 2010), and company positioning (Lawton, 1999). It remains that none of these cases empirically examine the ways in which Ryanair's standardized negotiation approach across its main stakeholder relationships has contributed to its success. On the contrary, we claim that most, if not all, of the cases written about Ryanair provide only a partial explanation for its success: while they unveil their cost-cutting strategy, they do not investigate how such deficits are achieved in practice. Finally, in addition to the numerous cases and articles on Ryanair, as well as public complaints and legal proceedings, the company voluntarily discloses plenty of information to the public, including content pertaining to negotiations, which would often be considered confidential elsewhere. This allows us, in a similar fashion to antecedent studies (Urbinati et al., 2018), to reconstruct in hindsight the institutionalization of their negotiation capability. In summary, we have chosen to present the Ryanair case study to support our enquiry because the airline is a good example of a firm that shows a unique and idiosyncratic way of addressing relationships with their stakeholders and exhibits an unambiguous relationship between its negotiation practices and performance. 


\subsection{Data collection and analysis procedure}

Theory building through case studies offers a wide variety of data collection options, mostly based on the availability of data for the researcher for the purpose of analysis (Eisenhardt and Graebner, 2007). For various reasons, we chose to rely on archival data and not to interview individuals who were working at Ryanair or were involved in negotiating with Ryanair. Firstly, as discussed, many sources relating to the company already exist both in the form of teaching materials and academic publications; there is therefore already a large amount of available information, and thus a serious risk of irrelevance. Secondly, Ryanair has a tendency not to cooperate and to circulate false information about its practices. We were therefore unsure as to whether or not we would be able to obtain direct data and, if we were to obtain it, whether we would be able to trust it. Thirdly, we are dealing here with a hidden source of competitive advantage, some form of trade secret, which makes the subject highly sensitive.

To ensure cross-comparison and triangulation, we collected data and information about negotiations in which Ryanair was involved from multiple published sources. In particular, we conducted a longitudinal analysis of articles published by relevant economic and aviation journals. Although the research took place between 2013 and 2017, investigated articles traced back to the early 2000s. In addition to this, we reviewed a large number of publicly available reports, legal proceedings, press releases, media reports, company statements, and airline reference websites, such as planespotters.net and flightglobal.com. Moreover, the researchers analyzed the large number of available interviews and public statements of Ryanair's CEO, Michael O'Leary (available on YouTube). Finally, we reviewed existing academic literature concerning Ryanair in the form of research articles (Casadesus-Masanell and Ricart, 2010; Kangis and O'Reilly, 2003; Lawton, 1999) and teaching case studies (notably from the Harvard Business Cases and The Case Centre; e.g., Borbély, 2014). Our analysis covered data both from Ryanair and from the stakeholders at large, e.g. unions, government agencies, and suppliers who negotiated with them. After having collected data and information, we conducted a content analysis (Weber, 1990), targeting the negotiation behavior of Ryanair.

Following established research techniques (Urbinati et al., 2018), we followed two specific steps to analyze secondary sources. To begin with, each author independently conducted a content analysis, applying within-case and cross-case explanation procedures. Each author then juxtaposed his own interpretation of the facts with the other authors, and a shared understanding and interpretation was reached. Authors then conducted conversations with a panel of experts in the field of negotiation, aviation, law, and strategic management, to 
discuss and corroborate the findings of the content analysis. The panel consisted of seven professors of either Strategy, Law, or Negotiation with world-class leading profiles (two from UCLA Anderson School of Management, one from IESEG School of Management, one from Monash Business School, one from Fisher College of Business, one from Marquette University, and one from Cleveland State University) along with a number of consultants and academics attending meetings of the International Association for Conflict Management and the Academy of Management, who participated in sessions where earlier versions of this research were presented. Each author subsequently conducted informal conversations and observations while flying with Ryanair and other airlines to corroborate previous findings. Finally, we triangulated the findings from each step to develop the case study.

\section{Case study: Ryanair}

\subsection{Introduction}

Low-cost carriers are specific airlines that offer limited services, most of them only medium-haul routes with no connections (Button, 2012). They keep their costs as low as possible and, at the same time, offer as many city pairs as possible in order to satisfy the maximum amount of customers. This means keeping planes flying for more hours per day, offering limited services onboard, having their personnel fly more than their competitors' for lower wages, and reducing the fees paid to airports (Hunter, 2006). To be as economical as possible, they must fit more passengers on every flight and, as such, they do not offer an upper class (which uses lots of floor space) and their fares are calculated to maximize seat occupancy (Button, 2012).

Ryanair operates a low fare, scheduled passenger service on short-haul and point-topoint routes between Ireland, the United Kingdom, Continental Europe, and Morocco. The company's fleet consists of more than 300 Boeing 737-800 aircraft, each equipped with 189 seats, the maximum allowed. The company offers over 1,600 flights per day, serving approximately 190 airports across Europe (Ryanair, 2016). Ryanair is actually a recent venture: it was founded in 1985 as a one-route operator between South-Eastern Ireland and London. After a rather bumpy start, it repositioned itself in the early 1990s and later took full advantage of the 1997 deregulation of the EU airspace, under which any European airline could fly out of any point in Europe, even if not located in their home country. Since then, Ryanair has experienced incredible growth, despite the global downturn in air travel following the terrorist 
attack on the World Trade Center in 2001. Although a market leader today, Ryanair aims to keep growing to fly a staggering 200 million passengers in the next ten years in comparison to circa 120 million passengers today. This would make it by far the largest air carrier in Europe (O’Leary, 2015).

It is important to understand that the airline industry scores reputably low in overall profitability (Smith et al., 1991; Morrison and Winston, 1995; Oum, Park, Kim, and Yu, 2004; Porter, 2008; Grant, 2010). When looking at the European market, most classical "flagship" airlines (notably Air France-KLM, IAG [British Airways and Iberia], and Lufthansa) struggle to break even. Ryanair is not only one of the rare financially healthy airlines, but also reports impressive financial results year after year (Ryanair posted a yearly profit of 866 million Euros in 2015), which is paradoxical considering their ultra-low cost pricing policy. In other words, how can an airline apply the lowest fares and be so profitable in such an unprofitable market?

\subsection{Pushing the no-frills logic a few steps further}

Ryanair's success has been widely investigated and most reasons justifying its success concern its industrial and marketing nature, focusing on Ryanair's cost structure and customervalue appropriation strategies (Lawton, 1999; Kangis and O'Reilly, 2003; Casadesus-Masanell and Ricart, 2010). Beyond these explanations, we believe that at the core of Ryanair's success lies a structured use of market dominance through negotiation to capture value across the board, not only with customers and employees, but first and foremost with airport operators and aircraft manufacturers. As demonstrated in the next section, the latter two categories supposedly hold market power over airlines due to the scarcity of the resources they offer (Porter, 2008).

With its customers and personnel, Ryanair applies a full 'no-frills' strategy. It has been able to impose very strict conditions on its pilots and stewards, even banning them from unionizing: wages are low and social coverage minimal (most employees being subject to the liberal Irish law). As it is one of the only airlines currently recruiting highly sought-after positions (cabin crews, pilots, etc.), Ryanair openly applies a 'take-it-or-leave-it' negotiation strategy with its personnel (Arnoux, 2013).

Quote 1: On June 19, 2009, BALPA (the U.K. pilots union) made a request for voluntary recognition under applicable U.K. legislation, which Ryanair rejected. (Ryanair, 2016)

Similarly, passengers pay for flying from point A to point B, nothing else: printing a boarding pass at the airport, checking luggage, or getting food onboard is possible but 
everything comes at a high price. Customer service is reduced to a bare minimum and aftersales service almost non-existent. Historically, fares could only be booked through the airline's website; only recently could travel agencies book Ryanair flights for their clients, and even this is under the best possible conditions for the airline as travel agencies cannot collect commission on these tickets.

Quote 2: Ryanair has negotiated an attractive per segment price and expects to sell tickets via travel agents at no commission to a mix of largely business/corporate travelers. (Ryanair, 2016)

In addition to applying sheer market power, which derives from resource scarcity, to restrict or, when possible, even eliminate their counterparts' negotiation margin, Ryanair has proven able to negotiate extremely advantageous deals like no one else in the market. While capturing the most financial value through these agreements, Ryanair still offers enough nonfinancial benefits to its stakeholders to make these deals possible. Indeed, both jobs at airlines and cheap airfares being rare resources on the market, they come at a high cost for isolated stakeholders that are unable to, or are prevented from, uniting.

Nothing thus far seems particularly novel: the firm uses its power over weaker stakeholders to gain value. Many firms adapt their recruitment, purchasing, and/or sales practices to their position on respective markets. The case of Ryanair is particularly worthy of interest because of the similarities between all of their organizational negotiation behaviors, revealing the existence of an underlying negotiation approach which is fully aligned with their positioning and strategic objectives - one that they use in most, if not all, of their stakeholder relationships. In other words, Ryanair uses consistent negotiation strategies not only against weak stakeholders, but also against more powerful ones, namely airports and aircraft manufacturers. In the next section, we cast a closer look at these two negotiation settings.

\subsection{Ryanair's special negotiation ingredient}

To use an airport, airlines usually pay landing fees (part service, part tax), plus variable fees depending on the services they use (time spent on the ground, gates, ground crews, maintenance, etc.). These fees are usually ultimately transferred to the airfare paid by the customers. To reduce these, Ryanair relies heavily on second-tier regional airports, whose operators are often in a weaker spot: they have invested a lot with little prospect of profitability and they are therefore eager to secure service from a major airline. When a platform like London Heathrow, used by major airlines, is saturated, landing rights are traded at high costs, 
which makes it a sellers' market. Conversely, Treviso (in Italy) or Vatry (in France) may be dying for a scheduled service by a major airline - a buyers' market in this case (Frazier and Kale, 1989; Taylor, 1995).

Quote 3: Ryanair's future growth also materially depends on its ability to access suitable airports located in its targeted geographic markets at costs that are consistent with Ryanair's strategy. (Ryanair, 2016)

Taking this into account, Ryanair has proven able not only to secure very low landing fees from regional airports, but also to collect 'marketing fees' from them. In other words, the airports operators pay Ryanair to serve their platforms, compensating, at least in part, the landing fees that the airline pays. One such negotiation may not amount to much, but on a scale of 190 airports, they amounted to about 660 million euros in 2008, a sum greater than Ryanair's profit that year (RFI, 2010). Furthermore, should an operator refuse to pay, or try to increase landing fees, Ryanair simply threatens to leave, even if still bound by a contract. This subject has been under several investigations carried out by the European Union and national courts in various States on the basis of public aid in disguise and alteration of fair competition (European Commission, 2014).

Quote 4: For example, in July 2012, the Spanish government increased airport taxes at the two largest airports, Barcelona and Madrid, by over 100\%, while smaller increases were implemented at other Spanish airports. As a result, Ryanair cancelled routes and reduced capacity on remaining routes from Madrid and Barcelona. (Ryanair, 2016)

The explanation usually provided is that Ryanair chooses second-tier airports because it places them in the most powerful situation, where they can impose their conditions in the easiest manner (e.g., Button, 2012; Casadesus-Masanell and Ricart, 2010). Looking at this from a negotiation perspective enables us to unveil how this negotiation strategy is, in fact, more complex. Ryanair aims to capture a lot of financial value from these deals to support their costcutting strategy. At the same time, Ryanair responds to lots of non-financial interests from their counterparts: service by a major airline, destinations, attractiveness for tourism, and business, as well as local jobs and political credit. In that sense, such deals are truly "win-win" (Lax and Sebenius, 1986) in that they are advantageous for both parties. This changes, of course, when Ryanair renegotiates or ends deals before their contractual termination date, arguing that local taxes are raised, or that their financial expectations are not being met. It remains that some 
airports, such as Beauvais in France, have gained tremendously from dealing with Ryanair. For example, Ryanair constitutes $84.6 \%$ of the traffic for Stansted Airport (CAPA Centre for Aviation, 2016), whose growth in the last years has been almost entirely driven by Ryanair's growth (The Manchester Airports Group, 2015).

A similar argument that has been provided to explain Ryanair's success is that the firm needs to have the lowest possible operating costs of their aircraft. A low-cost carrier will try to operate only one type of aircraft (the Boeing 737-800 in Ryanair's case) to enjoy savings from "fleet commonality" (i.e. by using a single type of aircraft, planes become interchangeable, making operations easier and, furthermore, pilots and stewards are allowed to fly all aircraft without having additional training). Such a strategy places the manufacturer in a de facto monopolistic position. Because transferring to a competitor comes at a such a high price, the airline is captive which, in theory, puts the manufacturer in a very favorable position to drive prices up in their negotiations with airlines (Porter, 1980, 2008).

To overcome this and reduce cost of ownership of their aircraft to the bare minimum, Ryanair must carefully play its relationship with Boeing. To do so, Ryanair has ordered planes in bulk at carefully chosen points in time. They placed major orders in 2003 (while the airline market was at an all-time low after the terrorist attacks of September 2001) and 2013-2014 (while Boeing was struggling with the battery problems of its 787 Dreamliner). In other words, Ryanair balances power at the negotiation table by ordering airplanes when their counterpart is in desperate need of good news. They then enhance the relationship by participating, once the deal is signed, in multiple media campaigns explaining how great Boeing products are (O'Leary, 2013). Such cross-marketing is a cheap investment and provides Ryanair with indirect, free publicity. In addition to this, in order to avoid being totally captive with Boeing, Ryanair also discusses with Airbus and is collaborating in the launch of a competing product from the Chinese manufacturer COMAC (Michaels, 2011).

These practices not only demonstrate the centrality of negotiation in Ryanair's strategy and operations, but they also show that Ryanair uses an idiosyncratic negotiation approach in most, if not all, of its key stakeholder relationships. Many firms structure some of their negotiation practices but few make use of a similar negotiation approach across the board with all stakeholders, powerful or weak. Even fewer go so far as being able to reverse unfavorable power balance relationships like Ryanair does. This tends to show that mastering negotiation techniques, not only at an individual level, but also at an organizational level, is key to Ryanair's success in an otherwise hostile environment. 
Quote 5: One of the stated objectives of Ryanair's strategic plan: Renegotiating contracts with existing suppliers, airports and handling companies. (Ryanair, 2016)

Ryanair's strategy to rule the market by offering ultra-low-fares to its customers, and to kill costs wherever possible cannot, alone, explain Ryanair's success. This needs to be coupled with the implementation of a strong negotiation strategy across most, if not all, stakeholder relationships in such an efficient way that it loosens the competitive forces and creates profitability (e.g., Chang and Lin, 2015; Perez and Pablos, 2003).

Casadesus-Masanell and Ricart (2010) offer an overall view of Ryanair's business model. Figure 1 is based on their analysis; it helps identify the key strategic elements of negotiations for Ryanair's success. Red circles and text represent our identification of Ryanair's unique and idiosyncratic way of negotiating. For example, what Casadesus-Masanell and Ricart refer to as the choice of having a standardized fleet of Boeing $737 \mathrm{~s}$, leading to a bargaining power with suppliers and lower maintenance costs, is the result of a strategic negotiation, in which Ryanair would not have had power were it not for its exceptional negotiation capability. The figure shows the ways in which successful negotiations may bridge a firm's strategic positioning through the success of its plan deployment. In the case of Ryanair, negotiation style is very aggressive on price, although it is respectful of the non-financial interests of their negotiation counterparts. We therefore posit that these negotiation practices contribute greatly to solving the paradox that exists between the airline's ultra-low fares Ryanair is by far the cheapest way to fly across Europe - and its ultra-high financial results. 
Figure 1 - Importance of Negotiations within Ryanair Business Model (adapted from Casadesus-Masanell and Ricart, 2010)

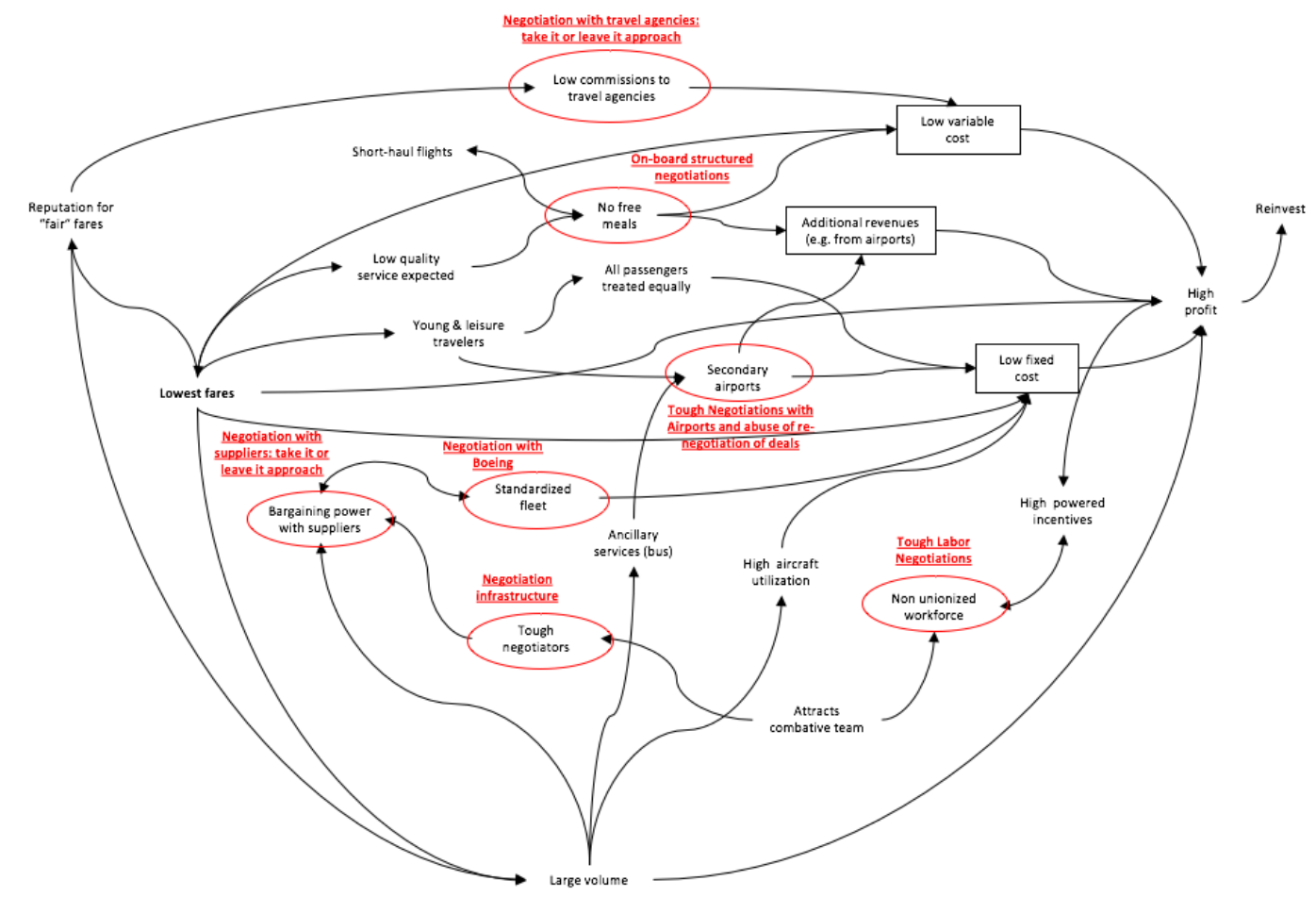

\section{Theory building: conceptual contributions from negotiation to strategy literature}

Looking at the Ryanair case specifically in terms of its negotiation practices enables us to identify unique and idiosyncratic processes of negotiation and link those directly to (1) their strategic positioning, i.e. what they are, what they aim to do, and the environment in which they evolve, and (2) their strategy's implementation, i.e. how effectively they implement their strategic choices. The case shows the means through which the Irish airline builds its strategic success, not only by cutting costs on their flying operations, but also rather through a structured negotiation approach towards all of their key stakeholders (Figure 1).

So far, most explanations of Ryanair's success have centered on its cost-killing appetite. It is therefore interesting to note that the Casadesus-Masanell and Ricart (2010) simplified business model for Ryanair does not take into account the underlying importance of negotiation in all aspects of their business model. Indeed, Casadesus-Masanell and Ricart, consistently with the mainstream approach of strategy scholars to negotiation, included the aspect of having tough negotiators in their model in order to support Ryanair's bargaining power. They do not, however, offer any explanation of such activity (i.e. the word negotiation is never used in their article). Conversely, we deem it to be key to the firm's success. It is our claim that cost-killing does not suffice to explain why the figures published by other European low-cost carriers are 
so far lower than Ryanair's, although these direct competitors rely on similar business recipes. Seeing as Ryanair is more profitable than the other European low-cost carriers by a significant margin, to the exception of EasyJet's most recent results, they must have something more than the competition. We argue that their ability to structure their negotiation practices with all of their stakeholders, not only a few of them, stands at the roots of their strategic success. This is where, as we will demonstrate in subsequent sections, our current strategic perspective on negotiation prevents us from fully understanding this phenomenon.

\subsection{The circularity between strategy and negotiation}

So far, in the field of strategy, negotiations have been mostly treated as a pure implementation tool, i.e. within the management practice (Dörrenbächer and Gammelgaard, 2006; Lippman and Rumelt, 2003; Luo and Shenkar, 2002). Figure 2, in its upper section, shows the static assumption of the literature. However, as the Ryanair case exemplifies, we suggest considering the relationship between strategy and negotiation as a dynamic cycle. In this, negotiation and strategy self-reinforce each other. For example, is Ryanair negotiating consistently because of its strategy and its positioning, or is Ryanair's negotiation capability allowing them to deploy their strategy and maintain their positioning? Unpacking this model requires looking at the contribution of negotiation to strategy, looking at the reverse relationship, and finally fitting negotiation within the definition of an organizational capability.
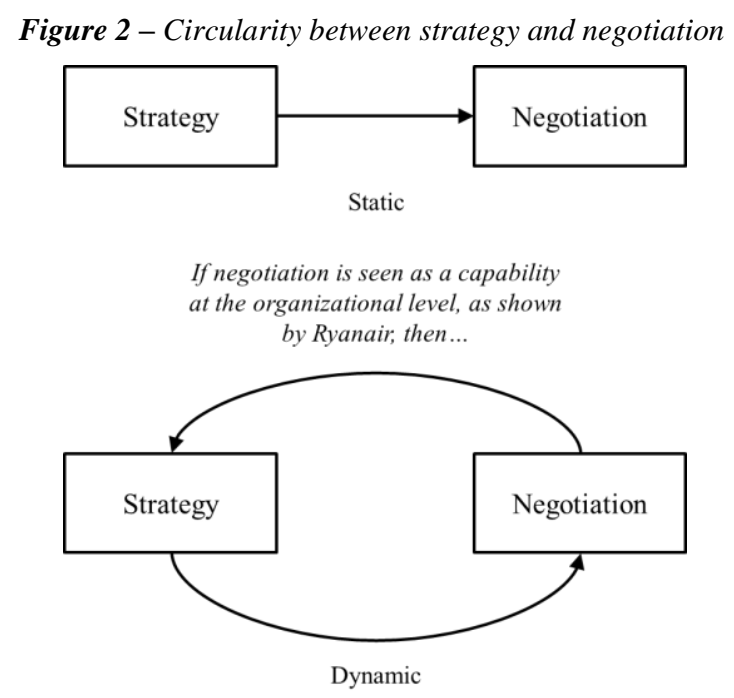

Negotiation practices contribute to strategy formulation and implementation. With no intention to forget other factors affecting strategic success (Grant, 2010), negotiation effectiveness may differentiate between the organizations that will thrive and those that will fail, no matter how good their strategy looks on paper (Mintzberg, 1994). Reading Mintzberg 
through a negotiation lens leads the reader to wonder at to what extent social dialogue, employee participation mechanisms and, more generally, negotiation practices within an organization may impact not only strategy formulation but also implementation. Such reasoning truly puts negotiation at the heart of the strategy process.

Conversely, individuals rarely negotiate for themselves but, instead, act on behalf of their team, department, business unit, or entire organization. Negotiation research clearly establishes that people negotiate differently depending on the organization they serve, which determines their role in the negotiation (Appelt and Higgins, 2010; McCracken et al., 2011). For example, Ryanair's explicit strategy allows negotiators to exhort more competitive behaviors when negotiating with local airports than classical airlines would do, as the threat of leaving the airport is high (Quote 4). Similarly, the same airport would not grant the same conditions to another airline.

By approaching the argument from a strategy perspective, this leads us to think about the influence of an organization's strategy and the strategic positioning of its agents' negotiation practices and negotiation effectiveness. However, this leaves unresolved the question of which strategy variables may fuel this circular relationship. We believe that there may be a number of these variables impacting the way people negotiate for the organization.

\subsection{Viewing negotiation as an organizational capability}

We argue that to exploit full benefits from this circular relationship, organizations may be wise to develop a true negotiation capability. This idea was first expressed by negotiation scholars tied to the Harvard's well-known Program on Negotiation (PON), namely Ertel (1999) and later Movius and Susskind (2009). In alignment with these two sources, we argue for a management approach to negotiation that takes an organization-wide perspective, i.e. looks at all negotiated exchanges at once, rather than one negotiation at a time.

In defining negotiation as a capability, we suggest integrating the negotiation literature with concepts drawn from the resource-based view theory (RBV), specifically the notion of dynamic capability (Eisenhardt and Martin, 2000; Helfat and Peteraf, 2003; Laaksonen and Peltoniemi, 2018; Teece and Pisano, 1994). RBV seeks to understand how competitive advantage is created and sustained over time, by focusing on the internal organization of firms (Wernerfelt, 1984). The underlying assumption of RBV is the conceptualization of firms as agglomerations of resources, which are heterogeneously distributed across firms and their capabilities. Scholars in this stream of theory argue that competitive advantage can be achieved and sustained if the firm possesses, through development or acquisition, resources that are 
valuable, inimitable, rare, and non-substitutable. This allows the firm to implement valuecreating and difficult-to-duplicate strategies (Allred et al., 2011). Teece and colleagues (1997) have integrated dynamism into RBV, pointing out that most environments in which firms compete are dynamic in the sense that the industry structure evolves at different speeds.

In their seminal article, Eisenhardt and Martin (2000) claimed that dynamic capabilities actually consist of the identifiable and specific routines that put resources into use. Some dynamic capabilities integrate resources, such as product development routines (e.g. Toyota). Strategic decision-making is considered to be a dynamic capability in which "managers pool their various business, functional, and personal expertise to make the choices that shape the major strategic moves of the firm" (Eisenhardt and Martin, 2000). Emerging from pathdependent histories of individual firms, dynamic capabilities are characterized as unique and idiosyncratic processes (Teece et al., 1997), although dynamic capabilities also exhibit common features that are associated with effective processes across firms (Eisenhardt and Martin, 2000). With no intention to enter the debate about the definition of capabilities (a recent review of the dynamic capability concept may be found in Laaksonen and Peltoniemi, 2018), for the purpose of our research we support Eisenhardt and Martin's definition of dynamic capabilities: "the firm's processes that use resources - specifically the processes to integrate, reconfigure, gain, and release resources - to match and even create market change. Dynamic capabilities, thus, are the organizational and strategic routines by which firms achieve new resource configurations as markets emerge, collide, split, evolve, and die" (Eisenhardt and Martin, 2000, p. 1107).

This enables us to define negotiation, from an organizational and strategic perspective, as a joint decision-making process (Lax and Sebenius, 1986) that is required in any organization to (1) integrate, e.g. joint ventures (Brouthers and Bamossy, 1997), mergers and acquisitions (Jemison and Sitkin, 1986; Dierickx and Koza, 1991) or interdepartmental exchange (Nauta and Sanders, 2000); (2) reconfigure, e.g. relationships with subsidiaries (Pahl and Roth, 1993; Dörrenbächer and Gammelgaard, 2006) or in strategic decision-making teams (Parayitam and Dooley, 2011); and (3) gain and release resources, e.g. sales and purchasing. In other words, it allows us to define negotiation as a dynamic capability.

We propose that such a negotiation capability is determinant for the firm's competitive advantage which, for example, differentiates Ryanair from its competitors, who largely lag behind in terms of profitability. Our analysis of Ryanair's success can be systematized by using Eisenhardt and Martin's (2000) model of dynamic capabilities (Table 2). 
Table 2 - Application of Eisenhardt and Martin's framework to the Negotiation Capability of Ryanair (Eisenhardt and Martin, 2000)

\begin{tabular}{lll}
\hline \hline & $\begin{array}{l}\text { Eisenhardt and Martin's } \\
\text { conceptualization of dynamic } \\
\text { capabilities }\end{array}$ & Ryanair's Negotiation capability \\
\hline Definition & $\begin{array}{l}\text { Specific organizational and strategic } \\
\text { processes by which managers alter their } \\
\text { resource base. }\end{array}$ & $\begin{array}{l}\text { Ryanair shows specific organizational and strategic } \\
\text { processes within its negotiations. }\end{array}$ \\
\hline Heterogeneity & $\begin{array}{l}\text { Commonalities (i.e. best practice) with } \\
\text { some idiosyncratic details. }\end{array}$ & $\begin{array}{l}\text { Ryanair masters largely common negotiation } \\
\text { strategies and tactics (e.g. take-it-or-leave-it) in an } \\
\text { idiosyncratic fashion that exploits its market } \\
\text { dominance. }\end{array}$ \\
\hline Pattern & $\begin{array}{l}\text { Depending on market dynamism, } \\
\text { ranging from detailed, analytic routines } \\
\text { to simple, experiential ones. }\end{array}$ & $\begin{array}{l}\text { Ryanair adapts negotiation behaviors to specific } \\
\text { markets and stakeholders. }\end{array}$ \\
\hline Outcome & $\begin{array}{l}\text { Depending on market dynamism, } \\
\text { predictable or unpredictable. }\end{array}$ & $\begin{array}{l}\text { Negotiation outcome depends on market dynamism, } \\
\text { predictable or unpredictable. }\end{array}$ \\
\hline $\begin{array}{l}\text { Competitive } \\
\text { Advantage }\end{array}$ & $\begin{array}{l}\text { Competitive advantage from valuable, } \\
\text { somewhat rare, equifinal, substitutable, } \\
\text { and fungible dynamic capabilities. }\end{array}$ & $\begin{array}{l}\text { Ryanair's negotiation capability is a fundamental } \\
\text { contribution to its competitive advantage. }\end{array}$ \\
\hline Evolution & $\begin{array}{l}\text { Unique path shaped by learning } \\
\text { mechanisms such as practice, } \\
\text { codification, mistakes, and pacing. }\end{array}$ & $\begin{array}{l}\text { Ryanair's negotiation capability has evolved over } \\
\text { time, taking advantage of external changes (e.g. the } \\
\text { 1997 deregulation of the market) and adapting to its } \\
\text { growing market dominance. }\end{array}$ \\
\hline \hline
\end{tabular}

We know that a dynamic capability has to take on the form of a "specific organizational and strategic process by which managers alter their resource base" (Eisenhardt and Martin, 2000). By analyzing Ryanair's negotiation behaviors, we can infer that negotiation for them is a specific process, largely adopted to alter their resource base (e.g., airport slots, airplanes, employee contracts, etc.). As we have argued, negotiation is a process (Zartman, 1977) centered on trade-offs broader than only the exchange of goods and services. In the words of Quélin and Duhamel, managers "should be able both to conduct negotiations for large scale contracts and provide guidelines for their businesses. In particular, they should be able to provide framework contracts to ensure a high level of consistency and cohesiveness in their organizations" (Quélin and Duhamel, 2003).

A second aspect of dynamic capabilities is that a firm demonstrating a dynamic capability shares commonalities, or best practices, with other firms in its industry, but also shows idiosyncratic details which make the analyzed firm different from the rest of its industry. Ryanair is an example of a firm with a successful, yet idiosyncratic, negotiating capability. They use largely known negotiation tactics, such as their 'take-it-or-leave-it' approach and information leaking, in an idiosyncratic fashion.

Thirdly, the pattern of effective dynamic capabilities is influenced by market dynamism. The pattern of negotiation capability shows the same dependence on market conditions. Indeed, Ryanair alternates the use of standardized negotiation practices to one-time 
experiences based on market dynamism and stakeholder characteristics. The negotiation capability relies, in some cases, on structured routines based on pre-existing knowledge (Kesting and Smolinski, 2007); in others, it will evolve through trial and error, simple, and experiential events. In such markets, pre-existing knowledge and experience may harm negotiation (Moran and Ritov, 2007), which makes the use of negotiation routines difficult.

Fourthly, the outcome of a capability follows the same general path as the pattern of the capability. In less dynamic markets, where negotiation capabilities are structured through routines and systems that allow less freedom of movement to the negotiators, the outcome of negotiations can be considered more predictable (Adair and Brett, 2005). Conversely, in highly dynamic markets, where emergent patterns of negotiation capability rely less on routines and more on experience, the outcome of negotiations is more difficult to predict (Lax and Sebenius, 1986).

In terms of contribution to competitive advantage, we have described the ways in which Ryanair's negotiation capability drives and sustains its competitive advantage. Competitive advantage is achieved through the possession of valuable resources for specific use, and additional value can be generated by combining the original resources of the firm with those of other firms (Lippman and Rumelt, 2003). Is negotiation a capability, able to bring competitive advantage if used appropriately? In Lippman and Rumelt's words: "in such a resource assembly, skill at bargaining and negotiation would further enhance value creation" (2003, p. 1082).

Finally, the negotiation capability has elements of an evolutionary process that follow a unique path, shaped by learning and experience. Although we have neglected to present a full longitudinal analysis of Ryanair's negotiation practices, their negotiation behaviors have changed and evolved over their history. Despite on-going controversies in negotiation theory about the exact role of learning and experience in increasing negotiation performance (Caputo, 2013), the body of research, nonetheless, shows that individual negotiation ability is definitely shaped by learning and experience (Ness and Haugland, 2005). One might not become a better negotiator over time, but ability in negotiation is a function of previous engagements. Negotiation could therefore be considered to be a dynamic capability of the firm.

Despite the scarcity of references shedding direct light on this issue, negotiation appears to play the role of a capability within a firm or an organization; more precisely, a dynamic capability, in the sense of Eisenhardt and Martin (2000). This leads us to present some operational advice, as well as some suggestions for future research. 


\subsection{Theoretical and practical implications: creating a negotiation capability}

Saying that negotiation should be considered an organizational capability is one thing; let us now attempt to explain how such a capability may be created and nurtured. Both Ertel (1999) and Movius and Susskind (2009) start with the idea that putting managers through classical negotiation training does not suffice to increase the organization's overall efficiency at negotiating in both a durable and substantial manner - it is a necessary, yet not sufficient, first step. Rather, they suggest a full audit of current negotiation practices, then a series of change efforts that rely on innovation diffusion (e.g., tailor-made training programs, analysis of practice, experience exchanges among practitioners, etc.) and adaptation and standardization of processes, such as the adoption of a unique negotiation preparation instrument (see for example Bell and Mandell, 2018). They also offer a range of reflections pertaining to aligning the negotiators' incentive structure with the organization's strategic goals (Movius and Susskind, 2009).

Going further, Ertel (1999) suggests adopting a different perspective on negotiation altogether, moving away from a situational approach to a more systematic and integrated one. He advocates coordinating all negotiations, not by creating stricter rules or mandates for negotiators, but instead by creating an exchange platform to support reports on all negotiations and exchange good practices, in addition to changing the incentive structure to better align the negotiators' objectives with the strategic goals they serve. To ensure that negotiators actually use their organization's strengths and act in the direction of the stated objectives requires a carefully crafted set of incentives and controls. For this, negotiators need to understand what their organization strategy is and have it tied to their objectives and bonus schemes.

Negotiation efficiency, defined as serving best the organization's objectives, may therefore involve innovative management control and human resource practices induced by the strategic forces of the firm. This could apply to a few functions of the firm (management, sales, HR, etc.) or, better, to the entire organization. The organization could then, much like Ryanair, benefit from increased coherence in their negotiation practices. Negotiation is thus a management issue which requires careful management practices. For example, some functions may have tools that could be used elsewhere; e.g. salespeople have periodic reviews of their negotiation practices, sometimes with a more experienced peer shadowing them in their interactions with a customer. Such insight into how they negotiate (and not the results they achieve) could be usefully transposed to social dialogue experts, or managers giving yearly evaluations to their subordinates. 
We propose adoption of the concept of "negotiation infrastructure" to describe all of the possible levers an organization has at its disposal to ensure its agents negotiate along the lines of its strategic objectives. Compiling an entire list of such levers is a complex task that remains to be tackled; this article only mentions a few. By this, we infer that an organization that considers its negotiations from a systemic perspective - and acts upon it - may through these means find some sources of performance. In other words, similarly to innovation, negotiation, seen and nurtured as a strategic capability, has the propensity to help firms unleash themselves from structural market constraints and support their competitive advantage (e.g., Natalicchio et al., 2017). Therefore, a systemic approach to negotiation should help organizations better achieve their strategic objectives.

All of this requires considering negotiation not from the sole perspective of behaviors (what happens at the negotiation tables), but through a strategic and managerial approach. Support for an integrated and systematic approach to negotiation from an academic perspective may be philosophically grounded in the studies of Zartman in terms of political negotiations (see for example, Ramsbotham and Schiff, 2018). Traditionally, negotiations have been approached through two mutually-exclusive lenses: mostly a behavioral one examining the human interactions at and around the negotiation table, with little concern for what is being negotiated; the other looking at the context of particular types of negotiations, such as employment relations (Stimec, 2014). The issue is that each approach is an unopened black box for the other one: the behavioral prism does not care about the context, nor the sources of complexity, of real-life negotiations, while the contextual approach does not look at the negotiations' behavioral elements. Zartman has long defended an integrated research approach that would combine behaviors and processes, which he materialized around a series of case studies drawn from complex geopolitical negotiations (Zartman, 1988). Such a philosophy would enable us to look at the entire corpus of negotiations an organization may experience, as one negotiation serves as the context for another one, but this has yet to transpire into business research. Zartman's approach supports the idea that negotiation can - and should - be approached in its entirety.

\section{Conclusions}

The Ryanair case study enabled us to show the clear link between performance in negotiation and the creation and sustainment of competitive advantage. At the same time, it clearly shows that what Ryanair achieves in negotiation would not be possible without the 
position the airline enjoys as a market leader. With this paper, we advance theory by providing an explanation as to why, under unfavorable market conditions and a business model that should not favor its bargaining power (e.g. suppliers in the case of the airline industry), some firms (e.g. Ryanair) can thrive and be successful by taking advantage of the structural weaknesses of their industry. The Ryanair case shows how a firm mastering negotiation as an organizational capability can turn the power relationship with its stakeholders into their own advantage. Our study proposes a model that shows the possibly reciprocal relationship between strategy and negotiation, as negotiation practices are influenced by the organization's strategy and, in turn, play a large role in strategy making, leading to competitive advantage. We have demonstrated that this circular relationship is fueled by some strategic variables and that the resulting capability may be nurtured by multiple management tools. However, our study, being novel and inductive, leaves room for refinement and opens up many questions for future research. One of them lies in the fact that success in negotiation is more than a quantitative result - "Did I negotiate well or not?" - but requires a subtle fit with the organization's positioning and strategic objectives. This requires a comprehensive categorization of the strategic factors that will have an impact on negotiations throughout the organization.

By no means do we want to support "a way" of negotiating, such as the hard bargaining of Ryanair; we rather propose that an organization that structures and nurtures a unique and idiosyncratic negotiation style could increase its chance of success and obtain a competitive advantage. We believe that what makes Ryanair successful is its harmonization and coherence in negotiating, aligned with the strategy of the firm, rather than a specific tactic. We also warn about a potentially dark side of negotiation capability, when interpreted as a way of extortion and abuse of power. Unfortunately, many business and political cases have reminded the world about the existence of this 'dark force'. Nevertheless, we suggest that a firm that negotiates to harm society and its stakeholders will not sustain its competitive advantage for long. Such ethical concerns are not the focus of our paper; however, future research might find profitable streams in bridging our theory with business ethics. For example, how long can Ryanair keep its negotiation style as it is, rather than go for a more relational and long-term approach? What are the externalities of such negotiation strategies, for example with reference to employee relations? The negotiation capability will need to evolve with the organization and its environment (Helfat and Peteraf, 2003). 


\subsection{Future research directions and limitations}

Several future research directions may lie in the advancement of research efforts related to the circular relationship between strategy and negotiation, in which several variables may have a role. A first variable that may impact the circularity between strategy and negotiation could be the market power. In the analysis of corporate behavior, when the literature in strategy refers to the concept of bargaining power (Porter, 1980), it does so mostly from an industrial economics perspective (Kim, 1988; Michael, 2000; Moatti et al., 2014). Such studies do not exactly tackle the issue of how organizations negotiate based on their bargaining power and that of their counterparts'. For example, according to this view, Ryanair should not have held the power that it had over Boeing, the unique possible supplier for its aircraft.

The characteristics of the market may also play an important role. People would certainly not negotiate in the same way with a firm enjoying a monopoly, or a strong oligopolistic situation, as with a firm dealing with a perfect competition setting (Machlup and Taber, 1960). This also applies to employers on specific markets, such as Ryanair for pilots, which may be the only ones recruiting in a specific region. Similarly, negotiators may have to select a different strategy depending on whether competition takes place with regards to price or to product or service characteristics. One may, therefore, posit that there are strong links between the market environment and the way that agents, on the ground, interact with the organization's stakeholders.

Similarly, we know little about what distinguishes a particularly innovative firm from its peers when negotiating with key stakeholders (e.g., Del Giudice et al., 2014). A firm that offers unique products or services may, just like a firm controlling rare resources, set its conditions to its clients, no matter how big and powerful they are. This may be more difficult to achieve for firms offering standard, substitutable products or services, which can only compete on price or secondary variables (such as geographic proximity). Thi has been established through a consolidate stream of research in strategy (Grant, 2010), which focuses mainly on demonstrating such dynamics and relationships rather than on explaining how, at an organizational level, those activities are performed. We therefore assume that relationships both internal and external, i.e. not only commercial but also, for example, employment relations - may be built on completely different grounds depending on the innovative nature of the firm, leading to systematically different negotiation practices.

Likewise, we may posit that one will not negotiate in the same way with a young firm - say, a start-up venture - as opposed to a well-established firm. We know that, for example, 
managers and entrepreneurs differ in their strategic decision-making processes according to the dimension and history of their organization (Busenitz and Barney, 1997). Similarly, the clients' dimension affects the auditors' behavior (Reynolds and Francis, 2000). Moreover, we know that contextual variables, such as a firm's relative competitive position in the market, influence the choice of negotiation behaviors of purchasing agents (Perdue and Summers, 1991). Beyond the question of size and, consequently, power, there may be a lifecycle argument (Mueller, 1972). Following a lifecycle approach, the introductory and rising phases may lead to different negotiation strategies than the maturity and decline phases (Helfat and Peteraf, 2003). In the former, it is about penetrating the market and potentially accepting suboptimal conditions, just to 'get out there'. As the product gains traction, the firm may set more stringent conditions to its clients, which is difficult to do for the early adopters, as they may not understand why the initial, more favorable terms are not renewed (Rink and Swan, 1979; Anderson and Zeithaml, 1984). Finally, in the decline phase, it may be about milking the cow one last time, with little consideration for the long-term relationship.

We also propose that the level of ambition of one's strategy may impact its negotiated processes, particularly the internal ones; a relationship mediated by the size and level of structuration of the organization (Welbourne and Pardo-del-Val, 2009). Simply put, a large, bureaucratic organization trying to completely turn itself around may harm its relationships with its key stakeholders, generating conflict and hardship for negotiators, for example, on the Human Resources' side of things (Beatty and Schneier, 1997). Conversely, a young and agile SME may more easily implement similar change and gain acceptance from its stakeholders (e.g., employees, financial backers, suppliers, and clients).

Future research might also focus on comparing the Ryanair experience with other successfully negotiating firms, in order to unveil common features associated with the best negotiating practices. Failure cases may also cast an interesting light on our research question. Let us consider the example of an event that took place in Air France, the French national air carrier. Like many others, Air France wanted to set up and develop a low cost subsidiary, to better compete with low cost carriers, such as Ryanair. However, the board's plan to develop Transavia, put forward in September 2014, described as the only way to address competition, was stalemated because of failed negotiations with the pilot unions (Clark, 2014). Air France may be successful in negotiating with some of its stakeholders, but its inability to push change through its unions may cripple its future strategic plans.

A limitation of our study is indeed its reliance on a single case. However, as explained in the research design section, in many occasions theory is built based on single cases that are 
particularly good at illuminating constructs when under investigation (Eisenhardt and Graebner, 2007). Future efforts in comparing cases will not only serve our understanding of negotiation, but also give us a more pragmatic vision of strategy making as a whole. For example, our research can help future research in the Strategy-as-Practice field of study (e.g., Jarzabkowski and Spee, 2009; Jarzabkowski and Whittington, 2008; Whittington, 1996), with such questions as: what is negotiation's contribution to strategizing? How can negotiation be positioned within the praxis, practitioners, and practices framework?

\section{Reference list}

Ackermann, F. and Eden, C. (2011), "Strategic management of stakeholders: theory and practice”, Long Range Planning, JOUR, Elsevier, Vol. 44 No. 3, pp. 179-196.

Adair, W.L. and Brett, J.M. (2005), “The Negotiation Dance: Time, Culture, and Behavioral Sequences in Negotiation", Organization Science, Institute for Operations Research and the Management Sciences, United States, Linthicum, Vol. 16 No. 1, pp. 33-51.

Allred, C.R., Fawcett, S.E., Wallin, C. and Magnan, G.M. (2011), “A Dynamic Collaboration Capability as a Source of Competitive Advantage”, Decision Sciences, Vol. 42 No. 1, pp. 129-161.

Anderson, C.R. and Zeithaml, C.P. (1984), "Stage of the product life cycle, business strategy, and business performance", Academy of Management Journal, Academy of Management, Vol. 27 No. 1, pp. 5-24.

Appelt, K.C. and Higgins, E.T. (2010), "My way: How strategic preferences vary by negotiator role and regulatory focus", Journal of Experimental Social Psychology, Vol. 46 No. 6, pp. 1138-1142.

Arnoux, G. (2013), “Je suis commandant de bord sur Airbus : Ryanair joue avec la sécurité de ses passagers", $L^{\prime} O B S$, available at: http://leplus.nouvelobs.com/contribution/879151-je-suis-commandant-de-bord-surairbus-ryanair-joue-avec-la-securite-de-ses-passagers.html (accessed 6 June 2013).

Beatty, R.W. and Schneier, C.E. (1997), "New HR roles to impact organizational performance: from“ partners' to ' players"”, Human Resource Management (1986-1998), Wiley Periodicals Inc., Vol. 36 No. 1, p. 29.

Bell, A. and Mandell, B. (2018), “Cognitive Maelstroms, Nested Negotiation Networks, and Cascading Decision Effects: Modeling and Teaching Negotiation Complexity with Systemic Multiconstituency Exercises”, Negotiation Journal, Wiley Online Library, 
Vol. 34 No. 1, pp. 37-67.

Borbély, A. (2014), "Negotiations, Ryanair-Style”, The Case Center, Vol. Ref. no. 3.

Brouthers, K. and Bamossy, G. (1997), “The role of key stakeholders in international joint venture negotiations: Case studies from Eastern Europe", Journal of International Business Studies, Palgrave Macmillan, United Kingdom, Washington, Vol. 28 No. 2, pp. $285-308$.

Busenitz, L.W. and Barney, J.B. (1997), "Differences between entrepreneurs and managers in large organizations: Biases and heuristics in strategic decision-making”, Journal of Business Venturing, Elsevier, Vol. 12 No. 1, pp. 9-30.

Button, K. (2012), “Low-Cost Airlines”, Transportation Journal, JSTOR, Vol. 51 No. 2, pp. $197-219$.

CAPA Centre for Aviation. (2016), "London Stansted: traffic growth is resurgent thanks to lower airport charges; Ryanair dominates", available at: http://centreforaviation.com/analysis/london-stansted-traffic-growth-is-resurgent-thanksto-lower-airport-charges-ryanair-dominates-261071 (accessed 12 February 2016).

Caputo, A. (2013), “A Literature Review of Cognitive Biases in Negotiation Processes”, International Journal of Conflict Management, Vol. 24 No. 4, pp. 274-398.

Casadesus-Masanell, R. and Ricart, J.E. (2010), "From strategy to business models and onto tactics”, Long Range Planning, Elsevier, Vol. 43 No. 2, pp. 195-215.

Chang, C.L. and Lin, T.-C. (2015), "The role of organizational culture in the knowledge management process", Journal of Knowledge Management, Emerald, Vol. 19 No. 3, pp. 433-455.

Clark, N. (2014), “Air France, after strikes, faces new uncertainty”, The New York Times, New York.

Dierickx, I. and Koza, M. (1991), “Information Asymmetries - How Not to 'Buy a Lemon' in Negotiating Mergers and Acquisitions”, European Management Journal, Blackwell Publishing Ltd., United Kingdom, London, Vol. 9 No. 3, p. 229.

Dörrenbächer, C. and Gammelgaard, J. (2006), "Subsidiary role development: The effect of micro-political headquarters-subsidiary negotiations on the product, market and valueadded scope of foreign-owned subsidiaries", Journal of International Management, Vol. 12 No. 3, pp. 266-283.

Eisenhardt, K.M. (1989), “Building Theories from Case Study Research”, Academy of Management Review, Vol. 14 No. 4, pp. 532-550.

Eisenhardt, K.M. and Graebner, M.E. (2007), “Theory building from cases: Opportunities 
and challenges", Academy of Management Journal, Vol. 50 No. 1, pp. 25-32.

Eisenhardt, K.M. and Martin, J.A. (2000), “Dynamic capabilities: what are they?”, Strategic Management Journal, John Wiley and Sons, Vol. 21 No. 10-11, pp. 1105-1121.

Elbanna, S., Ali, A.J. and Dayan, M. (2011), "Conflict in strategic decision making: do the setting and environment matter?", International Journal of Conflict Management, Vol. 22 No. 3, pp. 278-299.

Ertel, D. (1999), "Turning negotiation into a corporate capability", Harvard Business Review, Vol. 77, pp. 55-71.

European Commission. (2014), "State aid: Commission approves aid to manager of Altenburg-Nobitz Airport (Germany); orders recovery of incompatible aid from Ryanair”, Press Release, available at: http://europa.eu/rapid/press-release_IP-141153_en.htm (accessed 9 April 2015).

Frazier, G.L. and Kale, S.H. (1989), “Manufacturer-distributor relationships: a sellers' versus buyers' market perspective”, International Marketing Review, MCB UP Ltd, Vol. 6 No. 6.

Freeman, R.E. (2010), Strategic Management: A Stakeholder Approach, Cambridge University Press.

Del Giudice, M., Maggioni, V., Chase, R. and Chase, R. (2014), "Managerial practices and operative directions of knowledge management within inter-firm networks: a global view", Journal of Knowledge Management, Vol. 18 No. 5.

Grant, R.M. (2010), Contemporary Strategy Analysis and Cases: Text and Cases, John Wiley \& Sons.

Helfat, C.E. and Peteraf, M.A. (2003), “The dynamic resource based view: Capability lifecycles", Strategic Management Journal, Vol. 24 No. 10, pp. 997-1010.

Hunter, L. (2006), “Low Cost Airlines:: Business Model and Employment Relations”, European Management Journal, JOUR, Elsevier, Vol. 24 No. 5, pp. 315-321.

Jarzabkowski, P. and Paul Spee, A. (2009), "Strategy-as-practice: A review and future directions for the field", International Journal of Management Reviews, JOUR, Wiley Online Library, Vol. 11 No. 1, pp. 69-95.

Jarzabkowski, P. and Whittington, R. (2008), “A strategy-as-practice approach to strategy research and education", Journal of Management Inquiry, JOUR, SAGE Publications, Vol. 17 No. 4, pp. 282-286.

Jemison, D.B. and Sitkin, S.B. (1986), "Corporate acquisitions: A process perspective”, 
Academy of Management Review, Vol. 11 No. 1, pp. 145-163.

Kangis, P. and O'Reilly, M.D. (2003), "Strategies in a dynamic marketplace: A case study in the airline industry", Journal of Business Research, Elsevier, Vol. 56 No. 2, pp. 105111.

Kesting, P. and Smolinski, R. (2007), "When negotiations become routine: Not reinventing the wheel while thinking outside the box", Negotiation Journal, Wiley Online Library, Vol. 23 No. 4, pp. 419-438.

Kim, W.C. (1988), "The effects of competition and corporate political responsiveness on multinational bargaining power", Strategic Management Journal, Vol. 9 No. 3, pp. 289295.

Kummer, C. and Steger, U. (2008), "Why merger and acquisition (M\&A) waves reoccur: the vicious circle from pressure to failure", Strategic Management Review, Vol. 2 No. 1, pp. 44-63.

Laaksonen, O. and Peltoniemi, M. (2018), "The essence of dynamic capabilities and their measurement", International Journal of Management Reviews, Wiley Online Library, Vol. 20 No. 2, pp. 184-205.

Lawton, T.C. (1999), “The limits of price leadership: needs-based positioning strategy and the long-term competitiveness of Europe's low fare airlines”, Long Range Planning, Elsevier, Vol. 32 No. 6, pp. 573-586.

Lax, D.A. and Sebenius, J.K. (1986), The Manager as Negotiator: Bargaining for Cooperation and Competitive Gain, Macmillan, New York.

Lee, J.-R., Chen, W.-R. and Kao, C. (1998), "Bargaining power and the trade-off between the ownership and control of international joint ventures in China", Journal of International Management, Vol. 4 No. 4, pp. 353-385.

Lewicki, R.J., Saunders, D. and Barry, B. (2014), Negotiation, 7th ed., McGraw Hill, New York.

Lin, M.-L., Oh, E.-T., Liu, R.-J. and Hsu, P.-K. (2015), “An Intermediary’s Learning Business System: A Case Study of Gore-Tex”, Long Range Planning, JOUR, Elsevier.

Lippman, S.A. and Rumelt, R.P. (2003), “A bargaining perspective on resource advantage”, Strategic Management Journal, Vol. 24 No. 11, pp. 1069-1086.

Luo, Y. (1999), "Toward a conceptual framework of international joint venture negotiations", Journal of International Management, Vol. 5 No. 2, pp. 141-165.

Luo, Y. and Shenkar, O. (2002), “An empirical inquiry of negotiation effects in cross-cultural joint ventures”, Journal of International Management, Vol. 8 No. 2, pp. 141-162. 
Machlup, F. and Taber, M. (1960), "Bilateral monopoly, successive monopoly, and vertical integration", Economica, JSTOR, pp. 101-119.

Manzini, R., Lazzarotti, V. and Pellegrini, L. (2016), "How to Remain as Closed as Possible in the Open Innovation Era: The Case of Lindt \& Sprüngli”, Long Range Planning, JOUR, Elsevier.

Mazzola, P. and Kellermanns, F.W. (2010), Handbook of Research on Strategy Process, Edward Elgar Publishing, Cheltenham, UK.

McCracken, S., Salterio, S. and Schmidt, R. (2011), "Do Managers Intend to Use the Same Negotiation Strategies as Partners?", Behavioral Research in Accounting, American Accounting Association, United States, Sarasota, Vol. 23 No. 1, pp. 131-160.

Michael, S.C. (2000), "Investments to create bargaining power: the case of franchising", Strategic Management Journal, Vol. 21 No. 4, pp. 497-514.

Michaels, D. (2011), "Ryanair and Comac Forge Cooperating Agreement", The Wall Street Journal, 17 June, available at: http://www.wsj.com/articles/SB10001424052702303823104576391703163326520.

Mintzberg, H. (1994), Rise and Fall of Strategic Planning, Simon and Schuster.

Mintzberg, H., Ahlstrand, B. and Lampel, J. (1998), Strategy Safari, Vol. 2, Free Press, New York.

Mintzberg, H. and Lampel, J. (2012), "Reflecting on the strategy process", MIT Sloan Management Review.

Moatti, V., Ren, C.R., Anand, J. and Dussauge, P. (2014), "Disentangling the performance effects of efficiency and bargaining power in horizontal growth strategies: An empirical investigation in the global retail industry", Strategic Management Journal, John Wiley \& Sons, Ltd., Vol. 36 No. 5, pp. 745-757.

Moran, S. and Ritov, I. (2007), "Experience in integrative negotiations: What needs to be learned?", Journal of Experimental Social Psychology, Vol. 43 No. 1, pp. 77-90.

Morrison, S. and Winston, C. (1995), The Evolution of the Airline Industry, Brookings Institution Press.

Movius, H. and Susskind, L. (2009), Built to Win: Creating a World-Class Negotiating Organization, Harvard Business Press, Boston.

Mueller, D.C. (1972), “A life cycle theory of the firm”, The Journal of Industrial Economics, JSTOR, pp. 199-219.

Munduate, L., Euwema, M. and Elgoibar, P. (2012), Ten Steps for Empowering Employee Representatives in the New European Industrial Relations: New European Industrial 
Relations NEIRE Handbook, BOOK, McGraw Hill.

Nadler, J., Thompson, L. and Van Boven, L. (2003), "Learning negotiation skills: Four models of knowledge creation and transfer", Management Science, INFORMS Inst.for Operations Res.and the Management Sciences, Northwestern University, School of Law, 357 East Chicago Avenue, Chicago, IL 60611, United States, Vol. 49 No. 4, pp. 529540.

Natalicchio, A., Ardito, L., Savino, T. and Albino, V. (2017), "Managing knowledge assets for open innovation: a systematic literature review", Journal of Knowledge Management, Emerald Publishing Limited, Vol. 21 No. 6, pp. 1362-1383.

Nauta, A. and Sanders, K. (2000), "Interdepartmental negotiation behavior in manufacturing organizations", International Journal of Conflict Management, MCB UP Ltd, Vol. 11 No. 2, pp. 135-161.

Ness, H. and Haugland, S.A. (2005), "The evolution of governance mechanisms and negotiation strategies in fixed-duration interfirm relationships", Journal of Business Research, Elsevier, Vol. 58 No. 9, pp. 1226-1239.

O’Leary, M. (2013), “Ryanair's Big Boeing Order Win-Win for Both Sides: O’Leary”, Bloomberg Business, available at: https://www.youtube.com/watch?v=I8FonDQ5mhA (accessed 20 March 2014).

O’Leary, M. (2015), “Michael O’Leary, Ryanair CEO, British Irish Chamber of Commerce 2015 President's Gala Dinner", available at:

https://www.youtube.com/watch?v=e1t9YhJezak (accessed 25 November 2015).

Ogliastri, E. and Quintanilla, C. (2016), "Building cross-cultural negotiation prototypes in Latin American contexts from foreign executives' perceptions", Journal of Business Research, Elsevier, Vol. 69 No. 2, pp. 452-458.

Oum, T.H., Park, J.-H., Kim, K. and Yu, C. (2004), "The effect of horizontal alliances on firm productivity and profitability: evidence from the global airline industry", Journal of Business Research, Elsevier, Vol. 57 No. 8, pp. 844-853.

Pahl, J.M. and Roth, K. (1993), "Managing the headquarters-foreign subsidiary relationship: the roles of strategy, conflict, and integration", International Journal of Conflict Management, Vol. 4 No. 2, pp. 139-165.

Parayitam, S. and Dooley, R.S. (2011), "Is too much cognitive conflict in strategic decisionmaking teams too bad?", International Journal of Conflict Management, Vol. 22 No. 4, pp. 342-357.

Perdue, B.C. and Summers, J.O. (1991), “Purchasing agents' use of negotiation strategies”, 
Journal of Marketing Research, JSTOR, pp. 175-189.

Perez, J.R. and Pablos, P.O. de. (2003), "Knowledge management and organizational competitiveness: a framework for human capital analysis", Journal of Knowledge Management, Emerald, Vol. 7 No. 3, pp. 82-91.

Porter, M.E. (1980), Competitive Strategy, Free Press, New York.

Porter, M.E. (1996), "What is Strategy?", Harvard Business Review, Harvard Business School Publication Corp., Vol. 74 No. 6, pp. 61-78.

Porter, M.E. (2008), "The Five Competitive Forcs That Shape Strategy”, Harvard Business Review, Vol. 86 No. 1, pp. 78-93.

Quélin, B. and Duhamel, F. (2003), "Bringing together strategic outsourcing and corporate strategy:: Outsourcing motives and risks", European Management Journal, Vol. 21 No. 5, pp. 647-661.

Ramsbotham, O. and Schiff, A. (2018), "When Formal Negotiations Fail: Strategic Negotiation, Ripeness Theory, and the Kerry Initiative”, Negotiation and Conflict Management Research, Wiley Online Library.

Reynolds, J.K. and Francis, J.R. (2000), "Does size matter? The influence of large clients on office-level auditor reporting decisions", Journal of Accounting and Economics, Vol. 30 No. 3, pp. 375-400.

RFI. (2010), “Air France files complaint against Ryanair”, RFI English.

Ring, P.S. and van de Ven, A.H. (1994), "Developmental processes of cooperative interorganisational relationships", Academy of Management Review, Vol. 19 No. 350, pp. $90-118$.

Rink, D.R. and Swan, J.E. (1979), "Product life cycle research: A literature review", Journal of Business Research, Elsevier, Vol. 7 No. 3, pp. 219-242.

Ryanair. (2016), Annual Report 2015.

Salvato, C. (2009), "Capabilities unveiled: The role of ordinary activities in the evolution of product development processes", Organization Science, JOUR, INFORMS, Vol. 20 No. 2, pp. 384-409.

Shakun, M.F. (1991), “Airline Buyout: Evolutionary Systems Design and Problem Restructuring in Group Decision and Negotiation”, Management Science, Institute for Operations Research and the Management Sciences, Linthicum, United States, Linthicum, Vol. 37 No. 10, p. 1291.

Siggelkow, N. (2007), "Persuasion with case studies", Academy of Management Journal, Vol. 50 No. 1, pp. 20-24. 
Smith, K.G., Grimm, C.M., Gannon, M.J. and Chen, M.-J. (1991), “Organizational information processing, competitive responses, and performance in the US domestic airline industry", Academy of Management Journal, Academy of Management, Vol. 34 No. 1 , pp. $60-85$.

Stary, C. (2014), "Non-disruptive knowledge and business processing in knowledge life cycles - aligning value network analysis to process management", Journal of Knowledge Management, Emerald, Vol. 18 No. 4, pp. 651-686.

Stimec, A. (2014), "Vers une ingénierie des négociations dans les organisations", Recherches En Sciences de Gestion, ISEOR, Vol. 102 No. 3, pp. 195-212.

Taylor, C.R. (1995), “The long side of the market and the short end of the stick: Bargaining power and price formation in buyers', sellers', and balanced markets", The Quarterly Journal of Economics, JSTOR, pp. 837-855.

Teece, D. and Pisano, G. (1994), "The dynamic capabilities of firms: An introduction”, Industrial and Corporate Change, Vol. 3 No. 3, pp. 537-556.

Teece, D.J., Pisano, G. and Shuen, A. (1997), “Dynamic capabilities and strategic management", Strategic Management Journal, John Wiley \& Sons, Ltd., Vol. 18 No. 7, pp. 509-533.

The Manchester Airports Group. (2015), Annual Report 2014/2015.

Urbinati, A., Chiaroni, D., Chiesa, V., Franzò, S. and Frattini, F. (2018), “An exploratory analysis on the contextual factors that influence disruptive innovation: the case of Uber", International Journal of Innovation and Technology Management, World Scientific, p. 1850024.

Walsh, J.P. and Fahey, L. (1986), “The role of negotiated belief structures in strategy making”, Journal of Management, Vol. 12 No. 3, pp. 325-338.

Weber, R.P. (1990), Basic Content Analysis, Sage.

Weiss, S.E. (1990), "The long path to the IBM-Mexico agreement: an analysis of the microcomputer investment negotiations, 1983-86", Journal of International Business Studies, pp. 565-596.

Welbourne, T.M. and Pardo-del-Val, M. (2009), "Relational capital: strategic advantage for small and medium-size enterprises (SMEs) through negotiation and collaboration", Group Decision and Negotiation, Vol. 18 No. 5, pp. 483-497.

Wernerfelt, B. (1984), “A resource-based view of the firm”, Strategic Management Journal, Vol. 5 No. 2, pp. 171-180. 
Whittington, R. (1996), "Strategy as practice", Long Range Planning, JOUR, Elsevier, Vol. 29 No. 5, pp. 731-735.

Yan, A. and Gray, B. (2001), “Antecedents and Effects of Parent Control in International Joint Ventures", Journal of Management Studies, Vol. 38 No. 3, pp. 393-416.

Yin, R.K. (2014), Case Study Research: Design and Methods, edited by Bickman, L. and Rog, D.J.Essential Guide to Qualitative Methods in Organizational Research, Vol. 5, Sage publications, available at:https://doi.org/10.1097/FCH.0b013e31822dda9e.

Zartman, I.W. (1977), "Negotiation as a Joint Decision-Making Process", Journal of Conflict Resolution, Vol. 21 No. 4, pp. 619-638.

Zartman, I.W. (1988), "Common elements in the analysis of the negotiation process", Negotiation Journal, Springer, Vol. 4 No. 1, pp. 31-43. 